\title{
Tanggung Jawab Notaris terhadap Ketidaksesuaian Akta Salinan dengan Minuta Akta
}

\author{
Yoefanca Halim1凶, Fricky Soedewo2, Tyas Fidelia3 \\ 1,2,3 Fakultas Hukum Universitas Tarumanagara \\ E-mail: yoefancahalim.9a35@gmail.com
}

\begin{abstract}
Notary is a public official who has the authority to make authentic deeds and has other powers as referred to in this Law or based on other laws, as described in Article 1 number 1 of the Law on the Position of Notary Public. In carrying out his position, a Notary is required to act trustworthy, honest, thorough, independent, impartial, and safeguarding the interests of the parties concerned as well as making a Deed in the form of a Minute Deed. In addition, a Notary is required to issue a Grosse Akta, a Copy of the Deed, or a Quotation of the Deed based on the Minuta Deed. These matters are regulated in Law Number 2 of 2014 concerning Amendments to Law Number 30 of 2004 concerning the Position of Notary Public. By looking at these provisions, it is fitting for a Notary to carry out his obligations. But in reality, you can still find Notaries who do not carry out the obligations as stipulated in the Law on Notary Position. Starting from negligence in maintaining the Minuta Akta to differences between the Deed of Copy and the Minuta Akta. Of course, the difference between the Deed of Copy and the Minuta of the Deed will give losses to the parties who entered into an agreement. Regarding the responsibilities of a Notary Public, in general, it can be reviewed on a civil, criminal basis, the Law on the Position of Notary Public, and the responsibility for carrying out his / her duties based on the Notary's code of ethics. By looking at this raises a problem regarding, "What is the responsibility of the Notary for the non-conformity of the Copy Deed with the Minuta Deed?". The method used in this research is a normative or juridical legal research method.

Keywords: Notary, Deed, and Notary Responsibilities
\end{abstract}

\begin{abstract}
Abstrak
Notaris adalah pejabat umum yang berwenang untuk membuat akta autentik dan memiliki kewenangan lainnya sebagaimana dimaksud dalam Undang-Undang ini atau berdasarkan undangundang lainnya, sebagaimana dijelaskan dalam Pasal 1 angka 1 Undang-Undang Jabatan Notaris. Dalam menjalankan jabatannya, seorang Notaris diwajibkan untuk bertindak amanah, jujur, saksama, mandiri, tidak berpihak, dan menjaga kepentingan pihak yang terkait serta membuat Akta dalam bentuk Minuta Akta. Selain itu, seorang Notaris wajib mengeluarkan Grosse Akta, Salinan Akta, tau Kutipan Akta berdasarkan Minuta Akta. Hal-hal tersebut diatur dalam Undang-Undang Nomor 2 Tahun 2014 tentang Perubahan Atas Undang-Undang Nomor 30 Tahun 2004 tentang Jabatan Notaris. Dengan melihat ketentuan tersebut, sudah sepatutnya seorang Notaris melaksanakan kewajibannya. Namun pada kenyataannya, masih dapat ditemui Notaris yang tidak menjalankan kewajiban sebagaimana diatur dalam UU Jabatan Notaris. Mulai dari kelalaian dalam menjaga Minuta Akta sampai adanya perbedaan antara Akta Salinan dengan Minuta Akta. Tentu saja, dengan adanya perbedaan antara Akta Salinan dan Minuta Akta akan memberikan kerugian bagi para pihak yang mengadakan suatu perjanjian. Mengenai tanggung jawab Notaris, pada umumnya dapat dikaji secara pedata, pidana, UU Jabatan Notaris, dan tanggung jawab dalam menjalankan tugas jabatan berdasarkan kode etik Notaris. Dengan melihat hal tersebut memunculkan suatu permasalahan tentang, "Bagaimana tanggung jawab Notaris terhadap ketidaksesuaian Akta Salinan dengan Minuta Akta?". Metode yang digunakan dalam penelitian ini adalah metode penelitian hukum normatif atau yuridis.
\end{abstract}

Kata Kunci: Notaris, Akta, dan Tanggung Jawab Notaris 


\section{Pendahuluan}

Perikatan merupakan suatu hubungan hukum yang bersifat abstrak. Perkataan "Perikatan" (verbintenis) mempunyai arti yang lebih luas dari perkataan "Perjanjian"1. Dapat dikatakan bahwa perjanjian merupakan suatu hubungan hukum yang konkrit antar para pihak. Indonesia sebagai negara hukum tentu saja memiliki pengaturan mengenai perikatan. Hal tersebut diatur dalam Buku III Kitab Undang-Undang Hukum Perdata. Buku III itu, menganut asas "kebebasan" dalam hal membuat perjanjian (beginsel der contractsvrijheid).2 Artinya setiap orang dapat membuat perjanjian, asal tidak melanggar ketentuan yang telah ada.

Berbicara mengenai perjanjian, tidak lepas dari suatu jabatan atau profesi yang disebut sebagai Notaris. Menurut Pasal 1 angka 1 Undang-Undang Nomor 30 Tahun 2004 sebagaimana yang telah diubah dalam Undang-Undang Nomor 2 Tahun 2014 tentang Jabatan Notaris (yang selanjutnya disebut Undang-Undang Jabatan Notaris), Notaris adalah pejabat umum yang berwenang untuk membuat akta autentik dan memiliki kewenangan lainnya sebagaimana dimaksud dalam Undang-Undang ini atau berdasarkan undang-undang lainnya. 3 Notaris dalam menjalankan tugas dan jabatannya wajib berpedoman secara normatif kepada aturan hukum yang berkaitan dengan segala tindakan yang akan diambil untuk kemudian dituangkan dalam akta.4 Selain itu, Notaris wajib bertindak amanah, jujur, saksama, mandiri, tidak berpihak, dan menjaga kepetningan pihak yang terkait dalam perbuatan hukum sebagaimana diatur dalam Pasal 16 ayat (1) huruf a Undang-Undang Jabatan Notaris serta kewajiban lainnya adalah membuat akta dalam bentuk minuta akta dan menyimpannya sebagai bagian dari protokol notaris sebagaimana diatur dalam Pasal 16 ayat (1) huruf b.

Kedudukan Akta autentik mempunyai peranan penting dalam setiap hubungan hukum yang tercipta melalui suatu perjanjian, khususnya sebagai alat bukti yang sah apabila terjadi sengketa dikemudian hari. Pada dasarnya, Akta Autentik dibuat dalam bentuk yang telah ditentukan oleh Undang-Undang oleh atau di hadapan pejabat umum yang berwenang untuk itu di tempat akta itu dibuat, ketentuan ini diatur dalam Pasal 1868 Kitab Undang-Undang Hukum Perdata. Tentu saja dengan didukung oleh kata sepakat para pihak dalam membuat perjanjian, baik dalam jual beli, sewa menyewa, dan membuat anggaran dasar bagi berdirinya suatu Perseroan Terbatas.

Menjadi masalah apabila isi dari Akta Salinan dan Minuta Akta berbeda satu sama lain. Sebagai salah satu contoh dapat dilihat dalam Putusan Mahkamah Agung Nomor 2371 K/Pdt/2016, yang putusannya telah dibacakan pada 10 Januari 2017 menyatakan bahwa Permohonan Kasasi yang diajukan I Made Dapir dikabulkan dan membatalkan Putusan Pengadilan Tinggi Denpasar Nomor 182/PDT/2015/PTDPS, tanggal 30 November 2015 dan menguatkan Putusan Pengadilan Negeri Denpasar Nomor 766/Pdt.G/2014/PN Dps, tanggal 21 April 2015. Kasus bermula saat I Made Dapir menjual sebidang tanah Sertifikat Hak Milik Nomor 831 kepada Agus Suparmanto sebagai Termohon Kasasi, dengan bantuan Ida Ayu Indra Kondi Santosa, S.H., M.Kn, selaku Notaris/PPAT. Kesepakatan yang dituangkan dalam Akta Perjanjian Nomor 15, tertanggal 25 Juli 2011 memuat harga tanah sebesar Rp. 40.000.000.000,00 dan metode pembayaran yang akan dilakukan secara bertahap oleh pihak Termohon. Penambahan klausula juga menjadi kesepakatan para pihak, yang menyebutkan bahwa adanya denda $1 \%$ perbulan dari uang yang harus dibayarkan dalam hal keterlambatan pembayaran. Selain itu, uang yang telah dibayar hangus sehingga perjanjian batal demi hukum apabila dalam jangka waktu tiga bulan Termohon terlambat dalam melakukan pembayaran. Setelah akta perjanjian telah ditandatangani, seiring berjalannya waktu Termohon terlambat dalam melakukan pembayaran dan dikenakan denda $1 \%$ perbulan.

\footnotetext{
Subekti, Pokok-Pokok Hukum Perdata, (Jakarta: Intermasa, 2001), hlm. 122 Ibid. hlm. 127.

Indonesia, Undang-undang Nomor 30 Tahun 2004 tenntang Jabatan Notaris (Lembaran Negara Republik Indonesia Tahun 2004 Nomor 117, Tambahan Lembaran Negara Republik Indonesia Nomor 4432), Pasal. 1 Angka 1.

4 Cut Era Fitriyeni, “Tanggung Jawab Notaris Terhadap Penyimpanan Minuta Akta Sebagai Bagian Dari Protokol Notaris", Kanun Jurnal Ilmu Hukum Vol. 14 No. 58, 2012.
} 
Kosmik Hukum Vol. 20 No. 1 (2020): 35-44

E-ISSN: 2655-9242 | P-ISSN: 1411-9781

DOI: $10.30595 /$ kosmikhukum.v20i1.5410

Melihat hal demikian, Pemohon mengirim surat kepada Termohon dengan tembusan kepada Turut Termohon untuk membatalkan Akta Perjanjian Nomor 15, yang didasarkan pada klausula perjanjian. Akan tetapi, pihak Turut Termohon menyangkal adanya salah satu klausula yang menyatakan apabila ada keterlambatan pembayaran lebih dari tiga bulan, maka perjanjian batal demi hukum. Tentu saja hal ini terjadi perbedaan antara Akta Perjanjian Nomor 15 dengan Minuta Akta sehingga proses pengadilan harus ditempuh untuk menyelesaikan kasus tersebut. Pada tahap kasasi, secara ringkas putusan Mahkamah Agung menyatakan bahwa Akta Perjanjian tersebut adalah sah dan mempunyai kekuatan hukum mengikat. Pihak Termohon dikategorikan sebagai wanprestasi sehingga perjanjian batal demi hukum. Di sisi lain, Turut Termohon hanya diwajibkan untuk menyerahkan sertifikat hak milik nomor 831 kepada Pemohon dan membayar biaya perkara Bersama Termohon sebesar Rp. $500.000,00$. Apabila melihat putusan tersebut, tanggung jawab dari pihak notaris hanya sebatas mengembalikan sertifikat hak milik, meskipun kerugian telah diderita oleh pihak Pemohon dan Termohon cukup besar, baik materiil dan immateriil. Hal ini terjadi karena kelalain Turut Termohon selaku notaris yang mempunyai kedudukan penting dalam terciptanya Akta Perjanjian Nomor 15. Berdasarkan latar belakang tersebut, maka diangkatlah judul dari Jurnal ini adalah "Tanggung Jawab Notaris Terhadap Ketidaksesuaian Akta Salinan Dengan Minuta Akta".

\section{Rumusan Masalah}

Berdasarkan latar belakang di atas, maka permasalahan yang dikaji dalam artikel ini adalah bagaimana tanggung jawab notaris terhadap ketidaksesuaian Akta Salinan dengan Minuta Akta?

\section{Metodologi Penelitian}

Metode penelitian yang digunakan ialah normatif yuridis. Menurut Peter Mahmud Marzuki, penelitian hukum adalah suatu proses untuk menemukan aturan hukum, prinsipprinsip hukum, maupun doktrin-doktrin hukum guna menjawab isu hukum yang dihadapi.5 Menggunakan sumber bahan hukum primer, bahan hukum sekunder, dan bahan hukum tersier seperti UUD NRI 1945, Undang-Undang Nomor 2 Tahun 2014 tentang Perubahan Atas Undang-Undang Nomor 30 Tahun 2004 tentang Jabatan Notaris, Buku-buku maupun jurnal yang berkaitan dengan Tanggung Jawab Notaris Terhadap Ketidaksesuaian Akta.6

\section{Hasil Dan Pembahasan}

\section{Penyelesaian perselisihan hasil pemilihan Kepala Desa pasca lahirnya Undang- Undang No 6 Tahun 2014 Tentang Desa.}

Berdasarkan Pasal 1 angka 1 Undang-Undang Nomor 2 Tahun 2014 tentang Perubahan Atas Undang-Undang Nomor 30 Tahun 2004 tentang Jabatan Notaris (yang selanjutnya disebut UU Jabatan Notaris), menyatakan bahwa "Notaris adalah pejabat umum yang berwenang untuk membuat akta autentik dan memiliki kewenangan lainnya sebagaimana dimaksud dalam Undang-Undang ini atau berdasarkan undang-undang lainnya.". Profesi notaris adalah suatu profesi yang mulia (nobile officium), karena akta yang dibuat oleh notaris dapat menjadi dasar hukum atas status harta benda, dan menjadi dasar hak dan kewajiban seseorang. Kekeliruan atas akta yang dibuat notaris dapat menyebabkan hilangnya hak seseorang atau menyebabkan terbebaninya seseorang atas suatu kewajiban.7 Tugas notaris adalah

Peter Mahmud Marzuki, Penelitian Hukum, (Jakarta: Kencana Prenada Media Group, 2011), hlm. 35.

Peter Mahmud Marzuki, Penelitian Hukum, Cetakan ke-8, Edisi Revisi, (Jakarta: Kencana, 2013), hlm. 181.

Abdul Ghofur Anshori, Lembaga Kenotariatan Indonesia, Perspektif Hukum dan Etika, (Banten : UII Press, 2009), hlm. 7 
mengkonstatir hubungan hukum antara para pihak dalam bentuk tertulis dan format tertentu, sehingga merupakan suatu akta autentik. Notaris adalah pembuat dokumen yang kuat dalam suatu proses hukum.8 Pasal 1868 Kitab Undang-Undang Hukum Perdata, mengartikan akta autentik sebagai suatu akta yang dibuat dalam bentuk yang ditentukan oleh undang-undang, dibuat oleh atau di hadapan pejabat umum yang berkuasa untuk itu dan di tempat di mana akta dibuatnya.

Dalam menjalankan jabatannya, notaris mempunyai kewajiban sebagaimana yang tercantum dalam Pasal 16 UU Jabatan Notaris, dimana salah satu pada Pasal 16 ayat (1) huruf b disebutkan bahwa notaris berkewajiban "membuat akta dalam bentuk Minuta akta dan menyimpannya sebagai bagian dari Protokol Notaris". Dari Minuta akta ini berdasarkan Pasal 16 ayat (1) huruf d, notaris berkewajiban pula mengeluarkan Grosse Akta, Salinan Akta atau Kutipan Akta. Selain itu sebagaimana yang telah dijelaskan tersebut di atas, bahwa Salinan Akta yang dibuat oleh notaris didasarkan pada Minuta Akta hal ini didasarkan dari ketentuan Pasal 1 ayat (9) Undang-Undang Jabatan Notaris bahwa Salinan Akta adalah salinan kata demi kata dari seluruh akta dan pada bagian bawah salinan akta tercantum frasa "diberikan sebagai salinan yang sama bunyinya". Biasanya notaris tidak langsung seketika membuat Salinan Akta berdasarkan Minuta yang telah ia tandatangani. Hal yang Notaris lakukan adalah merapikan dengan mencatat perubahan-perubahan yang ada di dalam Minuta akta dalam selembar kertas, yang dapat terdiri dari penggantian, penambahan, pencoretan dan penyisipan berdasarkan pasal 48 ayat (2) UU Jabatan Notaris, hal mana perubahan tersebut dinamakan "renvoi" yang biasanya ditulis disisi kiri akta. Perubahan-perubahan tersebut yang kemudian dimasukkan (Inserting) dalam Salinan Akta yang akan dibuat, sehingga di dalam Salinan Akta sudah tidak ada lagi renvoi seperti pada Minuta akta sebelumnya. Dalam proses pembuatan Salinan akta, notaris atau pegawai notaris melakukan "calling" atau penyesuaian, dimana pihak yang satu membacakan Salinan Akta dan pihak yang lain menyesuaikan dengan Minuta Akta. Dengan demikian, kesesuaian terhadap bunyi dari Salinan akta terhadap Minuta Akta dapat tercapai. Hal ini dilakukan untuk mencegah adanya kekurangtelitian atau kekhilafan yang dapat menimbulkan masalah dikemudian hari serta Salinan akta yang dibuat oleh Notaris dapat dipertanggungjawabkan secara hukum dan memberi kepastian hukum terhadap orang yang berkepentingan langsung pada akta, ahli waris, atau orang yang memperoleh hak terhadap akta tersebut.9

Dalam praktiknya, walaupun telah diatur mengenai renvoi terkadang karena kekurang hati-hatian dalam mengambil tindakan dan megabaikan UU Jabatan Notaris, akta autentik lahir dan dapat mengakibatkan kerugian bagi para pihak. Saat membawa kerugian para pihak, notaris selaku pejabat pembuat akta autentik tersebut tentu tidak dapat melepaskan tanggung jawabnya. Tanggung jawab adalah suatu keadaan wajib menanggung yang dibebankan kepada subjek hukum yang melakukan perbuatan melawan hukum atau tindak pidana sehingga yang bersangkutan dapat dituntut untuk membayar ganti rugi dan/atau menjalankan pidana.10 Berkaitan dengan hal tersebut, notaris dapat diminta pertanggungjawabannya atas kebenaran materiil suatu akta yang keliru. Mengenai tanggung jawab Notaris selaku pejabat umum yang berhubungan dengan kebenaran materiil, Nico membedakannya menjadi empat poin, yakni11: 1) Tanggung jawab Notaris secara perdata terhadap kebenaran materiil terhadap akta yang dibuatnya; 2) Tanggung jawab Notaris secara pidana terhadap kebenaran materiil dalam akta yang dibuatnya ; 3) Tanggung jawab Notaris berdasarkan Peraturan Jabatan Notaris terhadap

\footnotetext{
Tan Thong Kie, Studi Notariat: Beberapa Mata Pelajaran dan Serba-Serbi Praktek Notariat, Buku I, Cetakan ke-2, (Jakarta: Ichtiar Baru Van Hoeve, 2007), hlm. 159.

9 Dedy Prasetyo Winarno, "Konsekuensi Yuridis Salinan Akta Notaris Yang Tidak Sama Bunyinya Dengan Minuta Akta Terhadap Keabsahan Perjanjian", Arena Hukum Volume 8 Nomor 3 Desember, 2015, hlm. 424.

10 Salim HS dan Erlies Septiana Nurbani, Penerapan Teori Hukum Pada Penelitian Disertasi dan Tesis Buku Kedua, (Jakarta: PT RajaGrafindo Persada, 2014), hlm. 208.

11 Nico, Tanggungjawab Notaris Selaku Pejabat Umum, (Banten: Center for Documentation and Studies of Business Law, 2003), hlm. 250
} 
Kosmik Hukum Vol. 20 No. 1 (2020): 35-44

E-ISSN: 2655-9242 | P-ISSN: 1411-9781

DOI: $10.30595 /$ kosmikhukum.v20i1.5410

kebenaran materiil dalam akta yang dibuatnya ; 4) Tanggung jawab Notaris dalam menjalankan tugas jabatannya berdasarkan kode etik Notaris.

\section{a. Tanggung Jawab Secara Perdata}

Secara Perdata, konstruksi yuridis yang digunakan untuk tanggung jawab Notaris terhadap kebenaran materiil suatu akta yang dibuat olehnya adalah konstruksi Perbuatan Melawan Hukum. Pasal 1365 Kitab Undang-Undang Hukum Perdata menyatakan bahwa "Tiap perbuatan melanggar hukum, yang membawa kerugian kepada seorang lain, mewajibkan orang yang karena salahnya menerbitkan kerugian itu, mengganti kerugian tersebut". Dalam ilmu hukum dikenal tiga kategori dari perbuatan melawan hukum, yaitu sebagai berikut:12

1. Perbuatan melawan hukum karena kesengajaan;

2. Perbuatan melawan hukum tanpa kesalahan (tanpa unsur kesengajaan maupun kelalaian);

3. Perbuatan melawan hukum karena kelalaian.

Adapun unsur-unsur dari Perbuatan Melawan Hukum yang disimpulkan dari ketentuan Pasal 1365 Kitab Undang-Undang Hukum Perdata, maka suatu Perbuatan Melawan Hukum haruslah mengandung unsur-unsur sebagai berikut:13

1. Adanya suatu perbuatan;

2. Perbuatan tersebut melawan hukum;

3. Adanya kesalahan dari pihak pelaku;

4. Adanya kerugian bagi korban;

5. Adanya hubungan kausal antara perbuatan dengan kerugian.

Dalam Putusan Kasasi Nomor 2371 K/Pdt/2016, yang putusannya telah dibacakan pada 10 Januari 2017 menyatakan bahwa Permohonan Kasasi yang diajukan I Made Dapir dikabulkan dan membatalkan Putusan Pengadilan Tinggi Denpasar Nomor 182/PDT/2015/PTDPS, tanggal 30 November 2015 dan menguatkan Putusan Pengadilan Negeri Denpasar Nomor 766/Pdt.G/2014/PN Dps, tanggal 21 April 2015. Kasus bermula saat I Made Dapir menjual sebidang tanah Sertifikat Hak Milik Nomor 831 kepada Agus Suparmanto sebagai Termohon Kasasi, dengan bantuan Ida Ayu Indra Kondi Santosa, S.H., M.Kn, selaku Notaris/PPAT. Kesepakatan yang dituangkan dalam Akta Perjanjian Nomor 15, tertanggal 25 Juli 2011 memuat harga tanah sebesar Rp. 40.000.000.000,00 dan metode pembayaran yang akan dilakukan secara bertahap oleh pihak Termohon. Penambahan klausula juga menjadi kesepakatan para pihak, yang menyebutkan bahwa adanya denda $1 \%$ perbulan dari uang yang harus dibayarkan dalam hal keterlambatan pembayaran. Selain itu, uang yang telah dibayar hangus sehingga perjanjian batal demi hukum apabila dalam jangka waktu tiga bulan Termohon terlambat dalam melakukan pembayaran. Setelah akta perjanjian telah ditandatangani, seiring berjalannya waktu Termohon terlambat dalam melakukan pembayaran dan dikenakan denda $1 \%$ perbulan.

Melihat hal demikian, Pemohon mengirim surat kepada Termohon dengan tembusan kepada Turut Termohon untuk membatalkan Akta Perjanjian Nomor 15, yang didasarkan pada klausula perjanjian. Akan tetapi, pihak Turut Termohon menyangkal adanya salah satu klausula yang menyatakan apabila ada keterlambatan pembayaran lebih dari tiga bulan, maka perjanjian batal demi hukum. Tentu saja hal ini terjadi perbedaan antara Akta Perjanjian Nomor 15 dengan Minuta Akta sehingga proses pengadilan harus ditempuh untuk menyelesaikan kasus tersebut. Pada tahap kasasi, secara ringkas putusan Mahkamah Agung menyatakan bahwa Akta Perjanjian tersebut adalah sah dan mempunyai kekuatan hukum

12 Munir Fuady, Perbuatan Melawan Hukum (Pendekatan Kontemporer), Cet.3, (Bandung : Citra Aditya Bakti,2010), hlm.3.

13 Ibid. hlm. 10 
mengikat. Pihak Termohon dikategorikan sebagai wanprestasi sehingga perjanjian batal demi hukum. Di sisi lain, Turut Termohon hanya diwajibkan untuk menyerahkan sertifikat hak milik nomor 831 kepada Pemohon dan membayar biaya perkara Bersama Termohon sebesar Rp. $500.000,00$. Bahwa apa yang dilakukan Turut Tergugat merupakan Perbuatan Melawan Hukum jika Turut Tergugat menyerahkan Sertifikat Hak Milik Nomor 887 kepada Penggugat, mengingat perjanjian sebagaimana tertuang dalam Akta Perjanjian Nomor 15 masih berlaku hingga pembayaran terakhir pada akhir bulan Mei 2015. Sehingga hal ini dapat mengakibatkan kerugian bagi Tergugat yang sejak awal memiliki itikad baik dan apabila melihat putusan tersebut, tanggung jawab dari pihak notaris hanya sebatas mengembalikan sertifikat hak milik, meskipun kerugian telah diderita oleh pihak Pemohon dan Termohon cukup besar, baik materiil dan immateriil. Hal ini terjadi karena kelalain Turut Termohon selaku notaris yang mempunyai kedudukan penting dalam terciptanya Akta Perjanjian Nomor 15.

\section{b. Tanggung Jawab Secara Pidana}

Terkait dengan kesalahan notaris, maka yang digunakan adalah beroepsfout. Istilah tersebut digunakan untuk kesalahan yang dilakukan oleh profesional dan jabatan-jabatan khusus termasuk notaris.14 Kesengajaan (dolus) menurut hukum pidana adalah perbuatan atau tindakan yang disadari, dimengerti dan diketahui sebagai demikian sehingga tidak ada unsur salah sangka atau salah paham.15 Sedangkan kealpaan (culpa) adalah terjadinya suatu perbuatan atau tindakan dikarenakan kurang hati-hati dan perbuatan tersebut bertentangan dengan kewajibannya. Perbuatan atau tindakan tersebut juga tidak terpikirkan terlebih dahulu mengenai akibatnya.16

Kesengajaan (dolus) di dalam hukum pidana memiliki beberapa bentuk, dimana tiap tiap bentuk dari kesengajaan ini memiliki pengertian dan sifat yang berbeda satu dengan yang lainnya, yakni:

\section{Kesengajaan sebagai maksud atau tujuan (Opzet alz Oogmerk);}

Apabila seseorang pada waktu ia melakukan suatu tindakan untuk menimbulkan suatu akibat yang terlarang, menyadari bahwa akibat tersebut pasti akan timbul ataupun mungkin dapat timbul karena tindakan yang akan atau sedang ia lakukan, sedangkan timbulnya akibat tersebut memang beoogd atau memang ia kehendaki maka apabila kemudian benar bahwa akibat tersebut telah timbul karena perbuatannya, orang dapat mengatakan bahwa orang tersebut mempunyai opzet als ogmerk terhadap timbulnya akibat yang bersangkutan.17

2. Kesengajaan dengan kesadaran/keinsyafan pasti atau keharusan (Opzet bij Zekerheidsbewustzijn);

Sandaran pada gradasi kesengajaan dengan keinsyafan kepastian ini terletak pada seberapa jauh pengetahuan atau kesadaran pelaku tentang tindakan dan akibat yang merupakan salah satu unsur dari suatu tindak pidana yang telah terjadi. Dalam hal ini termasuk tindakan dan akibat-akibat lainnya yang pasti/harus terjadi.18 Berdasarkan hal tersebut, dapat dikatakan bahwa dalam jenis opzet (kesengajaan) ini menjadi sandaran adalah akibat yang merupakan unsur daripada suatu delik.

3. Kesengajaan dengan kesadaran/keinsyafan kemungkinan (Opzet bij Mogelijkheidsbewustzjin).

\footnotetext{
14 Habib Adjie, Sanksi Perdata dan Administratif terhadap Notaris sebagai Pejabat Publik, (Bandung: Refika Aditama, 2008), hlm. 173.

15 Muljatno, Asas-asas Hukum Pidana, (Jakarta: Rineka Cipta,1993), hlm. 171

16 Roeslan Saleh, Perbuatan Pidana dan Pertanggungjawaban Pidana Dua Pengertian Dasar dalam Hukum Pidana, (Jakarta: Aksan Baru,1983), hlm. 125.

17 P. A. F. Lamintang, Dasar-dasar Hukum Pidana Indonesia, (Bandung: PT. Citra Aditya Bakti,1997), hlm. 312.

18 E. Y. Kanter dan S. R. Sianturi, Asas-asas Hukum Pidana di Indonesia dan Penerapannya, (Jakarta: Alumni AHMPTHM,1982), hlm. 177.
} 
Kosmik Hukum Vol. 20 No. 1 (2020): 35-44

E-ISSN: 2655-9242 | P-ISSN: 1411-9781

DOI: 10.30595/kosmikhukum.v20i1.5410

Kesengajaan dengan kesadaran dapat pula disebut sebagai suatu kesengajaan bersyarat atau dolus eventualis. Kesengajaan jenis ini bergradasi yang terendah, bahkan seringkali sukar dibedakan dengan kealpaan (culpa). Kesadaran jenis ini memiliki sandaran pada sejauh mana pengetahuan atau kesadaran pelaku tentang tindakan dan akibat terlarang beserta tindakan atau akibat lain yang mungkin terjadi.19

Pertanggungjawaban pidana mengandung asas kesalahan (asas culpabilitas), yang didasarkan pada keseimbangan monodualistik bahwa asas kesalahan yang didasarkan pada nilai keadilan harus disejajarkan berpasangan dengan asas legalitas yang didasarkan pada nilai kepastian. Walaupun Konsep berprinsip bahwa pertanggungjawaban pidana berdasarkan kesalahan, namun dalam beberapa hal tidak menutup kemungkinan adanya pertanggungjawaban pengganti (vicarious liability) dan pertanggungjawaban yang ketat (strict liability) 20

Rumusan Kitab Undang-Undang Hukum Pidana mengenai tindak pidana yang erat kaitannya dengan profesi Notaris adalah perbuatan pidana yang berkaitan dengan pemalsuan surat (Pasal 263), rahasia jabatan (Pasal 322 ayat (1)), dan pemalsuan yang dilakukan oleh pejabat (Pasal 416). Tiga pasal tersebut terkait dengan apa yang dikenal atau dikualifikasikan dengan pemalsuan surat (Valschheid in geschrif). Pemalsuan Surat pada ketentuan Pasal 263 dibatasi pada pemalsuan surat yang dapat menerbitkan suatu hak atau suatu perikatan atau suatu membebaskan dari utang dan pemalsuan surat yang ditujukan untuk membuktikan suatu kejadian.21

Dalam hal Notaris membuat Salinan akta yang tidak sesuai dengan Minuta Akta, dan ketidaksamaan itu menyangkut substansinya, maka oleh Mahkamah Agung dikategorikan sebagai tindak pidana membuat "Dokumen Palsu", dengan pertimbangan:22.

1. Ketentuan Pasal 1 ayat (9) Undang-Undang Jabatan Notaris "Salinan Akta adalah Salinan kata demi kata dari seluruh akta dan pada bagian bawah salinan akta tercantum frasa "diberikan sebagai salinan yang sama bunyinya".

2. Notaris adalah pejabat yang menjalankan profesi hukum sehingga Notaris adalah seorang intelektual atau profesional, karena itu Notaris harus tahu dampaknya bagi pihak lain dengan adanya ketidaksamaan Salinan Akta dengan Minuta Akta.

Seorang Notaris yang membuat Salinan Akta yang tidak sesuai dengan Minuta Aktanya merupakan pelanggaran terhadap kewajiban dalam menjalankan jabatannya yang telah diatur dalam Undang-undang Jabatan Notaris maupun Kode Etik Notaris, sehingga Notaris dapat dimintai pertanggungjawaban terhadap perbuatannya seperti contoh kasus Putusan Kasasi No. Nomor 2371 K/Pdt/2016 bahwa Ida Ayu Indra Kondi Santosa, S.H., M.Kn selaku Notaris/PPAT yang merupakan Turut Termohon menyangkal adanya salah satu klausula yang menyatakan apabila ada keterlambatan pembayaran lebih dari tiga bulan, maka perjanjian batal demi hukum. Akan tetapi, terjadi perbedaan antara Akta Perjanjian Nomor 15 dengan Minuta Akta. Oleh karena itu adanya itikad tidak baik dengan sengaja yang merugikan pihak Penggugat yang dilakukan oleh Turut Tergugat yang merupakan seorang Pejabat Notaris.

Secara Pidana, Notaris yang membuat Salinan tidak sesuai dengan Minuta aktanya dan ketidaksesuaian itu menyangkut substansinya dianggap membuat "Dokumen Palsu" berdasarkan ketentuan Pasal 263 ayat (1) Kitab Undang-Undang Hukum Pidana. Sedangkan Tanggung Jawab Notaris berdasarkan Undang-Undang Jabatan Notaris dan Kode Etik Notaris

Ibid. hlm. 178.

Barda Nawawi Arief, Masalah Penegakan Hukum dan Kebijakan Penanggulangan Kejahatan, (Bandung: PT. Citra Aditya Bakti, 2001), hlm. 23

21 Abdul Ghofur Anshori, Op.Cit., hlm. 38-41.

22 Alfa Tihanna Anwar, "Analisis Yuridis Terhadap Ketidaksesuaian Isi Salinan Akta Dengan Minuta Akta Notaris Dalam Perjanjian Kerja Sama (Studi Kasus : Putusan Pengadilan Negeri Pekanbaru Nomor 54/Pdt/G/2008/Pn.Pbr - Putusan Pengadilan Tinggi Riau Nomor 94/Pdt/2009/Ptr)", Tesis, 2011, hlm.77. 
diatur di dalam ketentuan sanksi sesuai dengan ketentuan Pasal 85 UndangUndang Jabatan Notaris dan ketentuan Pasal 6 Kode Etik Notaris Ikatan Notaris Indonesia.23

\section{c. Tanggung Jawab Berdasarkan UU Jabatan Notaris Dan Kode Etik Notaris}

Dalam menjalankan tugas jabatannya seorang notaris harus mematuhi berbagai ketentuan yang tersebut dalam UU Jabatan Notaris.24 Notaris dalam menjalankan tugas dan jabatannya tidak hanya harus taat kepada ketentuan peraturan perundang-undangan tetapi juga pada ketentuan yang telah disepakati bersama, yaitu ketentuan yang tertuang dalam kode etik profesinya dan ketentuan ini hanya berlaku bagi kalangan anggota profesi yang bersangkutan.25 Menurut Austin Fagothey, etika adalah studi tentang kehendak manusia, yaitu kehendak yang berhubungan dengan keputusan tentang yang benar dan yang salah dalam bentuk perbuatan manusia. Etika mencari dan berusaha menunjukan nilai-nilai kehidupan yang benar secara manusiawi kepada setiap orang.26 Tiga arti yang dapat dirumuskan untuk menjelaskan kata etika yaitu:

1. Nilai-nilai dan norma-norma moral yang menjadi pegangan bagi seseorang dan atau suatu kelompok dalam mengatur tingkah lakunya.

2. Kumpulan asas atau nilai moral yang dimaksud disini adalah kode etik, misalnya kode etik Advokat Indonesia, Kode etik Notaris Indonesia.

3. Ilmu tentang yang baik dan buruk.

Etika profesi adalah keseluruhan tuntutan moral yang terkena pada pelaksanaan suatu profesi, sehingga etika profesi memperhatikan masalah ideal dan praktek-praktek yang berkembang karena adanya tanggung jawab dan hak-hak istimewa yang melekat pada profesi tersebut, yang merupakan ekspresi dari usaha untuk menjelaskan keadaan yang belum jelas dan masih samar-samar dan merupakan penerapan nilai-nilai moral yang umum dalam bidang khusus yang lebih dikonkretkan lagi dalam kode etik.27 Sementara kode etik adalah nilai-nilai dan norma-norma moral yang wajib diperhatikan dan dijalankan oleh profesional hukum.28 Kode etik profesi dapat mencegah kesalahpahaman dan konflik serta mencerminkan moral dan nama baik dari anggota kelompok profesi itu sendiri. Hal tersebut sebagaimana ternyata pada uraian dalam Kode Etik Notaris Ikatan Notaris Indonesia, yakni:29

1. Etika kepribadian notaris;

2. Etika melakukan tugas dan jabatan;

3. Etika pelayanan terhadap klien;

4. Etika hubungan sesama rekan notaries; dan

5. Etika pengawasan terhadap notaris.

Hubungan antara kode etik dengan Undang-Undang Jabatan Notaris, terdapat di dalam ketentuan Pasal 4 UU Jabatan Notaris mengenai sumpah jabatan. Notaris melalui sumpahnya berjanji untuk menjaga sikap, tingkah laku dan akan menjalankan kewajibannya sesuai dengan kode etik profesi, kehormatan, martabat dan tanggung jawabnya sebagai Notaris. UU Jabatan Notaris dan Kode Etik Notaris menghendaki agar Notaris dalam menjalankan tugas jabatannya sebagai pejabat umum, selain harus tunduk pada UU Jabatan Notaris juga harus taat pada kode

Ibid. hal.24

Tan Thong Kie, Studi Notariat: Beberapa Mata Pelajaran dan Serba-Serbi Praktek Notariat, Buku I, Cetakan ke-2, (Jakarta: Ichtiar Baru Van Hoeve, 2000), hlm. 59.

25 Nico, Tanggung Jawab Notaris Selaku Pejabat Umum, (Yogyakarta: CDBSL), hlm. 276.

Aburarera Sukarno, dkk, Filsafat Hukum Teori dan Praktik, (Jakarta: Prenadamedia Group, 2013), hlm. 170.

27 Liliana Tedjosaputro, Etika Profesi Notaris dalam Penegakan Hukum Pidana, (Yogyakarta: Bayu Grafika, 1995), hlm. 9.

28 K. Bertens, Etika (Jakarta: Gramedia Pustaka Utama, 1997) hlm. 113.

29 Roenastiti, Op.Cit., hlm. 58 
Kosmik Hukum Vol. 20 No. 1 (2020): 35-44

E-ISSN: 2655-9242 | P-ISSN: 1411-9781

DOI: 10.30595/kosmikhukum.v20i1.5410

etik profesi serta harus bertanggung jawab terhadap masyarakat yang dilayaninya, organisasi profesi (Ikatan Notaris Indonesia atau INI) maupun terhadap negara.30

Dalam hal Notaris membuat Salinan Akta tidak sesuai dengan Minuta Akta, bahwa nyatalah Notaris telah melakukan pelanggaran terhadap kewajiban dalam menjalankan jabatannya yang telah ditentukan di dalam Pasal 16 ayat (1) huruf d yang menyatakan bahwa Salinan Akta dikeluarkan berdasarkan Minuta Akta. Selain itu, notaris melanggar kewajiban yang ditentukan dalam Pasal 16 ayat (1) huruf a UU Jabatan Notaris maupun Pasal 3 angka 4 Kode Etik Notaris Ikatan Notaris Indonesia, dimana notaris dalam menjalankan jabatannya, berkewajiban bertindak Jujur, yaitu tidak melakukan perbuatan yang menyimpang dari kepercayaan yang diberikan oleh klien (masyarakat); Saksama dalam arti bahwa seorang notaris harus cermat di dalam menguasai peraturan perundang-undangan agar akta autentik yang dibuatnya tidak melanggar atau bertentangan dengan peraturan perundang-undangan yang berlaku, berarti notaris dari waktu ke waktu wajib mengikuti peraturan perundangundangan yang dikeluarkan oleh pemerintah yang bertalian dengan profesi notaris; Mandiri yaitu notaris dalam menjalankan profesinya tidak terikat dengan salah satu lembaga/institusi, tidak berpihak dimana dalam membuat Akta Notaris, isinya tidak boleh menguntungkan salah satu pihak dan merugikan pihak yang lain; dan Menjaga kepentingan pihak yang terkait dalam perbuatan hukum, penuh rasa tanggung jawab serta harus pula menerapkan prinsip kehatihatian dalam setiap tindakan yang ia lakukan.31

Maka dalam hal Notaris tersebut melakukan pelanggaran terhadap kewajiban yang ditentukan di dalam ketentuan Pasal 16 ayat (1) huruf a dan huruf d UU Jabatan Notaris bahwa dalam menjalankan jabatannya Notaris berkewajiban bertindak jujur, saksama, mandiri, tidak berpihak, dan menjaga kepentingan pihak yang terkait dalam perbuatan hukum, dan memberikan pelayanan sesuai dengan ketentuan dalam Undang-Undang ini, kecuali ada alasan untuk menolaknya. Kemudian berdasarkan ketentuan Pasal 85 UU Jabatan Notaris, notaris yang bersangkutan dapat dikenai sanksi berupa:
a. Teguran lisan;
b. Teguran tertulis;
c. Pemberhentian sementara;
d. Pemberhentian dengan hormat; atau
e. Pemberhentian dengan tidak hormat.

Sedangkan sanksi di dalam ketentuan Pasal 6 Kode Etik Notaris Ikatan Notaris Indonesia, terhadap anggota yang melakukan pelanggaran Kode Etik dapat dikenakan sanksi berupa:

a. Teguran;

b. Peringatan;

c. Schorsing (pemecatan sementara) dari keanggotaan Perkumpulan;

d. Onzetting (pemecatan) dari keanggotaan Perkumpulan;

e. Pemberhentian dengan tidak hormat dari keanggotaan Perkumpulan.

Berdasarkan dari amar Putusan Kasasi No. 2371 K/Pdt/2016 bahwa menyatakan Akta Perjanjian Nomor 15 tertanggal 25 Juli 2011 yang dibuat Saudari Ida Ayu Indra Kondi Santosa, S.H., Mkn, Notaris di Kota Denpasar (Turut Tergugat) batal demi hukum. Dan menghukum kepada Turut Tergugat untuk menyerahkan sertifikat hak milik Nomor 831/Desa Kuta, seluas $7.520 \mathrm{~m} 2$ (tujuh ribu lima ratus dua puluh meter persegi) sebagaimana peta bidang tanah Nomor 1398/2008 Nomor Identifikasi Bidang (NIB) 00911 terletak di Provinsi Bali, Kabupaten Badung, Kecamatan Kuta, Desa Seminyak atas nama I Made Dapir kepada Penggugat. Yang mana seharusnya berdasarkan dari Pasal 85 UU Jabatan Notaris dan Pasal 6 Kode Etik 'Notaris' Saudari Ida Ayu Indra Kondi Santosa, S.H., Mkn, Notaris di Kota Denpasar (Turut Tergugat) dapat dikenakan sanksi peringatan dari Ikatan Notaris Indonesia (INI) karena apa yang

Abdul Ghofur Anshori, Op.Cit., hlm. 48.

31 Winanto Wiryomartani, "Pelanggaran Pidana/Perdata Dan Tindakan Indisipliner Oleh Notaris", (makalah disampaikan pada Seminar Minuta di Fakultas Hukum Universitas Indonesia, Depok, 23 Februari 2011), hlm. 2-4. 
dilakukan oleh Turut Tergugat mengakibatkan kerugian. Selain itu dalam Pasal 16 ayat (1) huruf a UU Jabatan Notaris maupun Pasal 3 angka 4 Kode Etik Notaris Ikatan Notaris Indonesia, dimana notaris dalam menjalankan jabatannya, berkewajiban bertindak Jujur, yaitu tidak melakukan perbuatan yang menyimpang dari kepercayaan yang diberikan oleh klien (masyarakat).

\section{Penutup}

Berdasarkan hasil pembahasan diatas, maka diperoleh kesimpulannya, yaitu bahwa notaris mempunyai kewajiban sebagaimana yang tercantum dalam Pasal 16 UU Jabatan Notaris, dimana salah satu pada Pasal 16 ayat (1) huruf b disebutkan bahwa notaris berkewajiban "membuat akta dalam bentuk Minuta akta dan menyimpannya sebagai bagian dari Protokol Notaris". Akta autentik lahir dan dapat mengakibatkan kerugian bagi para pihak. Saat membawa kerugian para pihak, notaris selaku pejabat pembuat akta autentik tersebut tentu tidak dapat melepaskan tanggung jawabnya, sehingga notaris dapat diminta pertanggungjawabannya atas kebenaran materiil suatu akta yang keliru. Notaris harus bertanggungjawab dalam melaksanakan kewajiban jabatannya baik secara perdata, pidana, maupun secara Undang-undang Jabatan Notaris dan Kode Etik Notaris. Contoh kasus berdasarkan Putusan Kasasi No. 2371 K/Pdt/2016 bahwa menyatakan Akta Perjanjian Nomor 15 tertanggal 25 Juli 2011 yang dibuat Saudari Ida Ayu Indra Kondi Santosa, S.H., Mkn, Notaris di Kota Denpasar (Turut Tergugat) batal demi hukum. Dan menghukum kepada Turut Tergugat untuk menyerahkan sertifikat hak milik Nomor 831/Desa Kuta, seluas 7.520 m2 (tujuh ribu lima ratus dua puluh meter persegi) sebagaimana peta bidang tanah Nomor 1398/2008 Nomor Identifikasi Bidang (NIB) 00911 terletak di Provinsi Bali, Kabupaten Badung, Kecamatan Kuta, Desa Seminyak atas nama I Made Dapir kepada Penggugat. Selain itu Turut Tergugat dapat dikenakan sanksi dalam UU Jabatan Notaris maupun Kode Etik Notaris yang diatur dalam Pasal 16 ayat (1) huruf a UU Jabatan Notaris maupun Pasal 3 angka 4 Kode Etik Notaris Ikatan Notaris Indonesia.

\section{Daftar Pustaka}

Adjie,Habib. Sanksi Perdata dan Administratif terhadap Notaris sebagai Pejabat Publik. (Bandung: Refika Aditama, 2008).

Anshori,Abdul Ghofur. Lembaga Kenotariatan Indonesia, Perspektif Hukum dan Etika. (Banten: UII Press, 2009).

Arief,Barda Nawawi. Masalah Penegakan Hukum dan Kebijakan Penanggulangan Kejahatan. (Bandung: PT. Citra Aditya Bakti, 2001).

Bertens,K. Etika. (Jakarta: Gramedia Pustaka Utama, 1997).

Fuady, Munir. Perbuatan Melawan Hukum (Pendekatan Kontemporer). Cet.3. (Bandung : Citra Aditya Bakti,2010).

HS, Salim dan Erlies Septiana Nurbani. Penerapan Teori Hukum Pada Penelitian Disertasi dan Tesis Buku Kedua. (Jakarta: PT RajaGrafindo Persada, 2014).

Kanter, E. Y. dan S. R. Sianturi. Asas-asas Hukum Pidana di Indonesia dan Penerapannya. (Jakarta: Alumni AHM-PTHM,1982).

Kie,Tan Thong. Studi Notariat: Beberapa Mata Pelajaran dan Serba-Serbi Praktek Notariat, Buku I, Cetakan ke-2, (Jakarta: Ichtiar Baru Van Hoeve, 2000).

Studi Notariat: Beberapa Mata Pelajaran dan Serba-Serbi Praktek Notariat, Buku I, Cetakan ke-2, (Jakarta: Ichtiar Baru Van Hoeve, 2007). 
Kosmik Hukum Vol. 20 No. 1 (2020): 35-44

E-ISSN: 2655-9242 | P-ISSN: 1411-9781

DOI: 10.30595/kosmikhukum.v20i1.5410

Lamintang, P. A. F. Dasar-dasar Hukum Pidana Indonesia. (Bandung: PT. Citra Aditya Bakti,1997).

Marzuki, Peter Mahmud. Penelitian Hukum. (Jakarta: Kencana Prenada Media Group,2011).

Kencana, 2013).

Penelitian Hukum, Cetakan ke-8, Edisi Revisi, (Jakarta:

Muljatno. Asas-asas Hukum Pidana. (Jakarta: Rineka Cipta,1993).

Nico. Tanggungjawab Notaris Selaku Pejabat Umum. (Banten: Center for Documentation and Studies of Business Law, 2003).

Tanggung Jawab Notaris Selaku Pejabat Umum. (Yogyakarta: CDBSL).

Saleh,Roeslan. Perbuatan Pidana dan Pertanggungjawaban Pidana Dua Pengertian Dasar dalam Hukum Pidana. (Jakarta: Aksan Baru,1983).

Subekti. Pokok-Pokok Hukum Perdata. (Jakarta: Intermasa, 2001).

Sukarno, Aburarera et al. Filsafat Hukum Teori dan Praktik. (Jakarta: Prenadamedia Group, 2013).

Tedjosaputro,Liliana. Etika Profesi Notaris dalam Penegakan Hukum Pidana. (Yogyakarta: Bayu Grafika, 1995).

Indonesia, Undang-undang Nomor 30 Tahun 2004 tenntang Jabatan Notaris (Lembaran Negara Republik Indonesia Tahun 2004 Nomor 117, Tambahan Lembaran Negara Republik Indonesia Nomor 4432).

Fitriyeni,Cut Era. “Tanggung Jawab Notaris Terhadap Penyimpanan Minuta Akta Sebagai Bagian Dari Protokol Notaris". Kanun Jurnal Ilmu Hukum Vol. 14 No. 58 Tahun 2012.

Winarno, Dedy Prasetyo. "Konsekuensi Yuridis Salinan Akta Notaris Yang Tidak Sama Bunyinya Dengan Minuta Akta Terhadap Keabsahan Perjanjian". Arena Hukum Volume 8 Nomor 3 Desember Tahun 2015.

Anwar, Alfa Tihanna. “Analisis Yuridis Terhadap Ketidaksesuaian Isi Salinan Akta Dengan Minuta Akta Notaris Dalam Perjanjian Kerja Sama (Studi Kasus : Putusan Pengadilan Negeri Pekanbaru Nomor 54/Pdt/G/2008/Pn.Pbr - Putusan Pengadilan Tinggi Riau Nomor 94/Pdt/2009/Ptr)". Tesis. (Depok: FH UI 2011).

Wiryomartani,Winanto. "Pelanggaran Pidana/Perdata Dan Tindakan Indisipliner Oleh Notaris". Makalah. Disampaikan pada Seminar Minuta. (Depok: Fakultas Hukum Universitas Indonesia, 23 Februari 2011). 